\title{
PERILAKU CYBERLOAFING TERHADAP KONTROL DIRI PADA PEGAWAI
}

\author{
Jerri Suranta ${ }^{1}$, Dwi Hurriyati ${ }^{2}$ \\ MahasiswaUniversitas Bina Darma ${ }^{1}$, Dosen Universitas Bina Darma ${ }^{2}$ \\ Jalan Jenderal Ahmad Yani No. 3 Palembang \\ Sur-el: jerri.suranta@gmail.com ${ }^{1}$,dwi.hurriyati@binadarma.ac.id ${ }^{2}$
}

\begin{abstract}
This study was conducted to determine the relationship between self-control and cyberloafing behavior. The hypothesis proposed in this study is that there is a positive relationship between self-control and cyberloafing behavior in staff. Subjects in this study amounted to 170 administrative employees in Palembang Hospital. The sample technique used in this study is simple random sampling technique. The measuring instrument used is the scale of self-control and Cyberloafing behavior. The analysis technique used is simple regression using SPSS version 20.0 The results of the analysis show that the correlation coefficient $(r)=0.515$ with the score obtained is $(R-$ square) $=0.265$ and $p=0.000$ ( $p<0.05$ and $p<0.01$ ) which means that the proposed hypothesis is accepted. These results indicate that there is a very significant relationship between self-control and cyberloafing behavior in administrative staff in Palembang Hospital. The variable contribution of self-control with cyberloafing behavior variable is $26.5 \%$.
\end{abstract}

Keywords : self control, cyberloafing behavior, and administrative staff.

Abstrak: Penelitian ini dilakukan untuk mengetahui adanya hubungan antara kontrol diri dengan perilaku cyberloafing pada pegawai rumah sakit di Palembang. Hipotesis yang diajukan dalam penelitian ini adalah bahwa ada hubungan antara kontrol diri dengan perilaku cyberloafing pada pegawai rumah sakit di Palembang. Subjek dalam penelitian ini berjumlah 170 pegawai administrasi di rumah sakit di Palembang. Teknik sampel yang digunakan pada penelitian ini adalah teknik simple random sampling. Alat Ukur yang digunakan adalah skala kontrol diri dan perilaku Cyberloafing. Teknik analisis yang digunakan yaitu regresi sederhana dengan menggunakan bantuan SPSS versi 20.0. Hasil analisis menunjukkan koefisien korelasi $(r)=0,515$ dengan skor yang didapatkan yaitu $(R-$ square $)=0,265$ dan $p=0,000(p<0,05$ dan $p<0,01)$ yang berarti hipotesis yang diajukan diterima. Hasil ini menunjukkan bahwa ada hubungan yang sangat signifikan antara kontrol diri dengan perilaku cyberloafing pada pegawai administrasi di rumah sakit di Palembang. Kontribusi variabel kontrol diri dengan variabel perilaku cyberloafing yaitu $26,5 \%$.

Kata Kunci : kontrol diri, perilaku cyberloafing, dan pegawai administrasi

\section{PENDAHULUAN}

Internet adalah salah satu teknologi yang telah berkembang dengan pesat. Dimana internet menjadi sebuah kebutuhan bagi kalangan banyak pengguna karena mampu mengakses dan mendapatkan informasi yang cepat dan mudah seperti masyarakat umum, pemerintah, pelajar, ibu rumah tangga, karyawan perusahaan, dan lain-lain. Jumlah pengguna internet di dunia pada tahun 2012 berkisar 2,4 miliar juta jiwa (Astri, 2014). Pengguna internet terbanyak berasal dari Asia yaitu 44,8\% dan diikuti 21,5\%
Eropa, kemudian disusul Amerika Utara 11,4\% (International Telecommunications Union, 2012). Besarnya jumlah pengguna internet di negara Asia sangatlah wajar mengingat lebih dari 55\% penduduk dunia berada di benua Asia. Indonesia menduduki urutan ke-4 sebagai negara dengan pengguna internet terbanyak di Asia yakni mencapai 55 juta jiwa pengguna (International World Stats, 2012). Tempat mengakses internet di Indonesia kebanyakan dari kantor $(52,4 \%)$, warnet/cafe/rental (35,1\%), rumah $(27,6 \%)$, sekolah/kampus (7,2\%), rumah teman/saudara 
$(3,7 \%)$, perpustakaan $(2,8 \%)$, dan hp $(0,4 \%)$ (Indonesian Consumer Profile, 2009). Hasil data survey tersebut memperlihatkan bahwa penggunaan internet tertinggi adalah di kantor. (Astri, 2014).

Internet menjadi sumber informasi yang paling banyak digunakan orang untuk mencari informasi yang dibutuhkan. Penggunaan internet untuk memenuhi kebutuhan sebagai sumber informasi dikarenakan mudah, cepat, tepat, murah dan akurat. Melalui internet pekerja dapat mengakses berbagai informasi sesuai dengan kepentingan pekerjaan mereka.

Pekerjaan dalam sebuah perusahaan adalah suatu proses kegiatan perencanaan, pengorganisasian, pengarahan, pengawasan, pengkoordinasian dan penilaian terhadap sumber, tatacara, dan kesanggupan yang tersedia untuk memenuhi tuntutan terhadap kesehatan, perawatan serta lingkungan yang sehat dengan jalan menyediakan dan menyelenggarakan berbagai upaya kesehatan yang ditujukan kepada perseorangan, keluarga, kelompok atau masyarakat (Azrul, 2010).

Internet memiliki banyak kelebihan yang tidak dimiliki oleh sumber informasi yang bersifat konvensional, informasi yang dapat diakses dari berbagai tempat tanpa dibatasi oleh jarak, ruang, dan waktu merupakan salah satu kelebihan yang dimiliki oleh internet memungkinkan pegawai untuk mendapatkan informasi yang berkaitan dengan pekerjaan mereka melalui akses informasi keberbagai sumber informasi yang ada di internet. Bila dilihat dari manfaat internet tersebut akan sangat membantu secara cepat proses kerja pegawai tersebut. Penggunaan teknologi internet ini dapat membantu tugas dan fungsi pegawai administrasi di rumah sakit Palembang dalam menjalankan tugas sebagai pelayan masyarakat

Di sisi lain, dengan adanya teknologi internet, seringkali didapati banyak pegawai yang hanya menggunakan internet lebih kepada kepentingan pribadi mereka antara lain hanya bermain game, browsing google dengan informasi selebritis, kemudian juga membuka jejaring sosial seperti facebook, twitter, instagram, whatsApp messenger dan lain-lain. Terdapat dampak negatif juga bagi institusi, yaitu pegawai dapat melalaikan kewajiban dalam melaksanakan tugas dan fungsi di institusi. Misalnya, mengakses internet pada waktu jam kerja dengan tujuan bukan untuk kepentingan pekerjaan, tetapi hanya untuk menghilangkan kebosanan di kantor, perilaku inilah yang disebut dengan cyberloafing.

Perilaku Cyberloafing menurut Anadarajan dan Simmers (Sari, 2014) merupakan tindakan sengaja dari pegawai menggunakan akses internet perusahaan untuk kepentingan yang tidak berhubungan dengan pekerjaan di saat jam kerja. Perilaku cyberloafing ini dapat dikatakan sama dengan istilah personal web usage at work (penggunaan jaringan pribadi saat bekerja). Personal web usage at work merupakan segala bentuk perilaku online web yang dilakukan oleh pegawai secara sengaja selama jam kerja dengan menggunakan 
berbagai sumber daya organisasi untuk aktivitas selain dari keperluan pekerjaan yang ditentukan. Sumber daya organisasi yang dimaksud tidak hanya berupa jaringan maupun server perusahaan, tetapi juga penggunaan komputer dan waktu pegawai yang seharusnya menjadi sumber daya milik perusahaan (Sari, 2014)

Menurut Utama dkk (2016), perilaku cyberloafing didefinisikan sebagai tindakan sengaja pegawai menggunakan akses internet perusahaan selama jam kerja untuk mengakses situs serta menerima dam mengirimkan surat elektronik dengan tujuan yang tidak berhubungan dengan pekerjaan. Garret \& Danziger (Utama dkk, 2016) memberikan definisi perilaku cyberloafing yang lebih ringkas, yaitu penggunaan pribadi yang tidak sah atas akses internet yang diberikan perusahaan selama jam kerja.

Karakteristik perilaku cyberloafing menurut zhang dkk (2015) ada tiga, antara lain; 1) perilaku cyberloafing tidak terlihat seperti perilaku loafing (kegiatan yg membuang waktu) lainnya. Pelaku cenderung susah diidentifikasi apakah sedang melakukan hal tersebut atau tidak karena aktivitas cyberloafing tidak membutuhkan pegawai untuk absen atau tidak berada tempat kerja dalam waktu yang lama dan tidak membutuhkan aktivitas fisik yang terlihat seperti menghabiskan waktu makan siang yang lama, mengobrol sesama karyawan, dan lain-lain. Pelaku dapat melakukan aktivitas cyberloafing tanpa harus meninggalkan meja kerjanya contohnya browsing, chatting, dan sebagainya; 2) kegiatan tersebut menyebabkan kerugian yang serius pada produktifitas pegawai; 3) kegiatan tersebut mengurangi keuntungan dan manfaat dari perusahaan atau organisasi..

Menurut Ozler \& Polat (Ardilasari, 2016), terdapat tiga faktor munculnya perilaku cyberloafing yaitu; (1) Faktor Individual Berbagai atribut dalam diri individu tersebut antara lain persepsi dan sikap, sifat pribadi yang meliputi shyness, loneliness, isolation, kontrol diri, harga diri dan locus of control, kebiasaan dan adiksi internet, faktor demografis, keinginan untuk terlibat, norma sosial dan kode etik personal; (2) Faktor Organisasi Faktor organisasi juga dapat menentukan kecenderungan pegawai untuk melakukan cyberloafing yaitu pembatasan penggunaan internet, hasil yang diharapkan, dukungan manajerial, pandangan rekan kerja tentang norma cyberloafing, sikap kerja pegawai dan karakteristik pekerjaan yang pegawai lakukan; (3) Faktor Situasional Perilaku menyimpang internet biasanya terjadi ketika pegawai memiliki akses terhadap internet di tempat kerja sehingga hal ini sangat dipengaruhi oleh faktor situasional yang memediasi perilaku ini. 
Ozler \& Polat (2012) menyatakan bahwa salah satu faktor yang mempengaruhi perilaku cyberloafing adalah sifat pribadi pegawai, yaitu kontrol diri. Sedangkan Menurut chak dkk (2004) kecanduan internet atau kegiatan cyberloafing memiliki hubungan dengan rendahnya kontrol diri dan disiplin dari perilaku cyberloafing

Menurut Ghufron \& Risnawati (2012), kontrol diri diartikan sebagai kemampuan individu untuk menyusun, membimbing, mengatur, dan mengarahkan bentuk perilaku yang dapat membawa ke arah konsekuensi positif. Kontrol diri antara satu individu denganindividu yang lain berbeda-beda. Ada individu yang memiliki kontrol diri tinggi, sedang, atau bahkan rendah.

Menurut Delisi dkk (Paramitha, 2016) karakteristik dalam kontrol diri, ada beberapa komponen didalam individu yang mempunyai kontrol diri rendah yaitu; 1) Implusif; 2) Mementingkan diri sendiri; 3) Mencari tugas yang sederhana; 4) Mengambil kegiatan yang berisiko; 5) Memilih kegiatan yang berhubungan dengan fisik dan temperamen.

Berdasarkan uraian masalah di atas, maka peneliti tertarik untuk meneliti mengenai hubungan antara kontrol diri dengan perilaku cyberloafing pada Pegawai.

\section{METODOLOGI PENELITIAN}

\section{Identifikasi Variabel Penelitian dalam penelitian ini adalah Variabel}

Tergantung : Perilaku

Cyberloafing dan

Variabel Bebas

: Kontrol Diri

Perilaku cyberloafing adalah perilaku pegawai administrasi yang menggunakan akses internet perusahaan untuk hal-hal yang tidak berkaitan dengan pekerjaan di saat jam kerja di RSUD Palembang BARI. Variabel ini diungkap dengan menggunakan skala yang disusun penulis berdasarkan aspekaspek yang dikemukakan oleh Utama dkk (2016), yaitu : perilaku cyberloafing mengganggu, perilaku cyberloafing rekreasional dan perilaku cyberloafing pembelajaran pribadi..

Kontrol diri adalah kemampuan para pegawai administrasi di rumah sakit dalam mengatur dan mengarahkan pikiran, afeksi, dan perilaku agar dapat beradaptasi dengan lingkungan dengan tujuan untuk memenuhi kebutuhan maupun melawan godaan tertentu. Variabel ini di ungkap dengan skala kontrol diri yang disusun oleh penulis berdasarkan aspek-aspek yang dikemukakan oleh Ghufron \& Risnawati (2014), yaitu: kontrol perilaku, kontrol kognisi, dan kontrol keputusan.

Populasi adalah wilayah generalisasi yang terdiri dari obyek atau subyek yang mempunyai kualitas dan karakteristik tertentu yang ditetapkan oleh peneliti untuk dipelajari dan kemudian ditarik kesimpulannya. Sampel adalah bagian dari jumlah dan karakteristik yang dimiliki oleh populasi tersebut (Sugiyono, 2013).. 
Populasi dalam penelitian ini adalah pegawai rumah sakit Palembang. Sampel dalam penelitian ini berjumlah 170 pegawai. Berdasarkan cara perhitungan sampel menurut Isaac dan Michael (Sugiyono, 2013) dengan taraf kesalahan 5\% maka diperoleh sampel sebanyak 114 pegawai. Sebelum pelaksanaan penelitian dilakukan uji coba skala atau TO (Try Out) terlebih dahulu sebanyak 56 orang pegawai yang diambil dari sisa populasi digunakan sebagai sampel penelitian.

Metode pengumpulan data merupakan suatu cara yang digunakan oleh peneliti untuk mendapatkan data. Metode pengumpulan data yang digunakan dalam penelitian ini adalah dengan metode skala. Azwar (2012) menjelaskan bahwa skala adalah perangkat pertanyaan yang disusun untuk mengungkap atribut tertentu melalui respon terhadap pertanyaan tersebut.

Skala yang digunakan dalam penelitian ini adalah skala psikologi yang terdiri atas skala perilaku cyberloafing dan kontrol diri. Skala yang digunakan merupakan model skala likert yang dibuat dalam bentuk checklist $(\sqrt{ })$. Skala perilaku cyberloafing dan kontrol diri ini terdiri dari dua bentuk pernyataan, yaitu berupa pernyataan yang mendukung (favourable) dan pernyataan yang tidak mendukung (unfavourable).

Analisis data yang digunakan dalam penelitian ini adalah analisis statistik. Sebelum dilakukan uji hipotesis terlebih dahulu dilakukan uji prasyarat yaitu uji normalitas dan uji linieritas. Oleh sebab itu dilakukan pengambilan sampel menggunakan metode random sampling.

\section{HASIL DAN PEMBAHASAN}

Berdasarkan data yang diperoleh melalui tahap uji coba alat ukur, selanjutnya dilakukan uji validitas dan reliabilitas. Perhitungan untuk menguji validitas dan reliabilitas, dimana skala perilaku cyberloafing yang berjumlah 60 aitem kemudian dilakukan analisis aitem, peneliti menggunakan batas minimum koefisien korelasi 0,30 sehingga diperoleh 45 aitem yang valid dan 15 aitem yang gugur, $\mathrm{Uji}$ reliabilitas pada perilaku cyberloafing menunjukkan nilai reliabilitas alpha sebesar 0,964. Sedangkan skala kontrol diri yang berjumlah 60 aitem dan terdiri dari 30 pernyataan favourable dan 30 pernyataan unfavourable telah dilakukan analisis validitas dengan batas minimum koefisien korelasi 0,30 , nilai uji reliabilitas pada skala kontrol diri menunjukkan reliabilitas sebesar 0,957

Gambaran umum mengenai data penelitianSkor empirik merupakan skor yang didapat dilapangan. Mean empirik pada variabel perilaku cyberloafing sebesar 108,46 dengan standar deviasi 16,436. Mean empirik pada kontrol diri sebesar 95,00 dengan standar deviasi 11,977. Sedangkan skor hipotetik merupakan skor yang diharapkan dapat dicapai oleh sampel penelitian. Mean hipotetik pada variabel perilaku cyberloafing sebesar 157,5 dengan standar deviasi 7,5. Mean hipotetik pada 
variabel kontrol diri sebesar 161 dengan standar deviasi 7,6.

Berdasarkan hasil dari kedua data yang diperoleh melalui alat ukur yang dibuat oleh peneliti berdistribusi normal karena memenuhi kaidah $\mathrm{p}>0,05$, dapat dilihat dari nilai $\mathrm{p}$ alat ukur tersebut yaitu perilaku cyberloafing $\mathrm{p}=0,727(\mathrm{p}>0,05)$ dengan KS$\mathrm{Z}$ 0,693 dan kontrol diri nilai $\mathrm{p}=0,865(\mathrm{p}>$ 0,05) dengan KS-Z 0,599.

Hasil uji linieritas antara kontrol diri dengan perilaku cyberloafing dalam penelitian Berdasarkan tabel diatas nilai $\mathrm{F}$ merupakan koefesien yang menunjukkan hubungan antara variabel bebas dan variabel terikat dengan nilai $\mathrm{F}=40,375$ dan $\mathrm{p}=0,000$. Nilai $\mathrm{p}$ merupakan nilai yang menunjukkan seberapa linier hubungan antara variabel bebas dan variabel terikat. Tabel di atas nilai $\mathrm{p}=0,000<0,01$ sehingga menunjukkan bahwa terdapat hubungan yang linier antara kontrol diri dengan perilaku cyberloafing.

Berdasarkan hasil perhitungan statistik yang telah dilakukan untuk membuktikan bahwa terdapat hubungan yang sangat signifikan antara kontrol diri dengan perilaku cyberloafing pegawai administrasi rumah sakit Palembang. Analisis dilakukan dengan menggunakan uji regresi sederhana yang hasilnya menunjukkan adanya penerimaan terhadap hipotesis yang diajukan. Hasil tersebut dapat dilihat dari nilai koesifien korelasi $\mathrm{r}=0,515$ dengan nilai signifikansi $(\mathrm{p})=0,000$ atau dengan kata lain $\mathrm{p}$ $\leq 0,01$. Ini menunjukkan bahwa ada hubungan yang sangat signifikan antara kontrol diri dengan perilaku cyberloafing pegawai administrasi rumah sakit Palembang.

Besarnya nilai sumbangan kontrol diri (variabel bebas) dengan perilaku cyberloafing (variabel terikat) adalah nilai $\mathrm{R}$ square $=0,265$ atau $26,5 \%$. Berdasarkan hasil sumbangan tersebut menunjukan bahwa kontrol diri berpengaruh positif terhadap perilaku cyberloafing pegawai administrasi rumah sakit Palembang.

Kontrol diri yang tinggi dan terus berlanjut akan menghasilkan dampak perilaku cyberloafing baik terhadap perilaku cyberloafing pegawai administrasi. Pegawai administrasi yang memiliki dampak buruk terhadap perilaku cyberloafing adalah pegawai yang memiliki kontrol diri rendah. Kontrol diri ini memiliki kecenderungan lebih besar untuk terlibat dalam perilaku menyimpang di tempat kerja. Biasanya sifat pegawai yang mempunyai kontrol diri rendah terlibat dalam perilaku cyberloafing. Dari hasil deskripsi berdasarkan kategorisasi perilaku cyberloafing bahwa dari sebanyak 114 pegawai administrasi rumah sakit Palembang yang dijadikan subjek penelitian, terdapat 65 pegawai administrasi atau $57,1 \%$ yang memiliki perilaku cyberloafing baik dan 49 pegawai administrasi atau 42,9\% yang memiliki perilaku cyberloafing buruk. Sehingga dapat disimpulkan rata-rata pegawai administrasi rumah sakit Palembang memiliki perilaku cyberloafing baik. .

Jurnal Ilmiah PSYCHE Vol.12 No.2 Desember 2018:81 - 90 
Demikian sesuai dengan fenomena yang di temukan peneliti di lapangan, dimana para pegawai mempunyai produktivitas yang baik. Pegawai hanya menggunakan internet untuk sekedar mencari hiburan semata. Seperti mengakses status di jaringan sosial, chatting, mengunjungi situs-situs berita dan olahraga, serta mengirim dan membuka email. Karena bagi pegawai tindakan tersebut diperlukan untuk mengurangi kebosanan kerja bahkan dapat mendorong kreativitas, fleksibilitas, persahabatan dan saling percaya antar pegawai ketika melakukan kegiatan bersama serta mendorong terciptanya lingkungan pembelajaran.

Karakteristik perilaku cyberloafing menurut Zhang dkk (2015) ada tiga, antara lain, yaitu: a. perilaku cyberloafing tidak terlihat seperti perilaku loafing (kegiatan yg membuang waktu) lainnya. Pelaku cenderung susah diidentifikasi apakah sedang melakukan hal tersebut atau tidak karena aktivitas cyberloafing tidak membutuhkan pegawai untuk absen atau tidak berada tempat kerja dalam waktu yang lama dan tidak membutuhkan aktivitas fisik yang terlihat seperti menghabiskan waktu makan siang yang lama, mengobrol sesama karyawan, dan lain-lain. Pelaku dapat melakukan aktivitas cyberloafing tanpa harus meninggalkan meja kerjanya contohnya browsing, chatting, dan sebagainya, b. kegiatan tersebut menyebabkan kerugian yang serius pada produktifitas pegawai, c. kegiatan tersebut mengurangi keuntungan dan manfaat dari perusahaan atau organisasi

Hal ini sesuai dengan penelitian Ozler dan Polat (2012), bahwa self control merupakan kemampuan individu untuk menyusun, membimbing, mengatur, dan mengarahkan bentuk perilaku yang dapat membawa kearah konsekuensi positif. Self control antara satu individu dengan individu yang lain berbeda-beda. Apabila individu mempunyai self control dan integritas yang tinggi mereka lebih jarang terlibat dalam perilaku menyimpang di tempat kerja. Oleh karena itu self control berhubungan dalam menentukan perilaku yang dilakukan individu saat bekerja, apakah perilaku yang bersifat produktif atau sebaliknya. Individu bisa dikatakan produktif apabila ia menggunakan fasilitas internet sesuai dengan kebutuhan. Hal ini akan terhindar dari perilaku cyberloafing. Tingkat self control pada individu juga menunjukkan kemampuannya dalam mengatur dan mengarahkan perilakunya kearah konsekuensi yang positif. Sedangkan individu yang mempunyai tingkat self control yang rendah cenderung lebih besar untuk melakukan perilaku cyberloafing.

Dari hasil deskripsi berdasarkan kategorisasi kontrol diri bahwa dari 
sebanyak 114 pegawai administrasi rumah sakit Palembang yang dijadikan subjek penelitian, terdapat 59 pegawai administrasi atau 51,8\% yang memiliki kontrol diri tinggi dan 55 pegawai administrasi atau 48,2\% yang memiliki kontrol diri rendah. Sehingga dapat disimpulkan rata-rata pegawai administrasi rumah sakit Palembang memiliki kontrol diri rendah.

Menurut Robinso dan Bennett (2008), individu yang memiliki kontrol diri tinggi dapat lebih mampu untuk meninjau situasi, menahan godaan dan mengalihkan perhatian mereka dari perilaku merugikan seperti cyberloafing. Sebaliknya apabila individu memiliki kontrol diri rendah, mereka memiliki keperluan yang kuat terhadap perilaku terlarang saat bekerja, seperti perilaku cyberloafing.Meskipun perilaku cyberloafing dapat memiliki efek positif misalnya meningkatkan kreatifitas pegawai, perilaku cyberloafing memiliki konsekuensi yang mahal bagi instansi yang membiarkan perilaku ini tetap dilakukan oleh pegawainya. Layaknya perilaku melalaikan pekerjaan lainnya, perilaku cyberloafing dapat menyebabkan komputer menjadi banjir akan sumber daya komputasi dengan penggunaan internet untuk kepentingan pribadi, dan selanjutnya akan menyebabkan degradasi sistem komputer. Perilaku cyberloafing juga menyebabkan instansi bertanggung jawab hukum akan perilaku pegawai seperti pelecehan, pelanggaran hak cipta, fitnah, pekerjaan ditinggalkan. Hasil studi empiris mengenai perilaku cyberloafing bahwa perilaku cyberloafing memiliki prevalensi dan konsekuensi yang merusak di tempat pekerja. Bagi para pemberi kerja cyberloafing dapat memunculkan konsekuensi yang negatif karena penyimpangann produksi yang berakibat cyberloafers merugikan instansi.

Demikian sesuai dengan fenomena yang di temukan peneliti di lapangan yaitu para pegawai yang mempunyai kontrol diri dan integritas yang tinggi mereka lebih jarang terlibat dalam perilaku menyimpang di tempat kerja. Para pegawai tersebut lebih mementingkan pekerjaan mereka dan mampu menunda kepuasan dengan segera untuk mengatur perilakunya ketika bekerja. Hal ini terlihat ketika laporan pekerjaan mereka sedang di tunggu oleh pimpinan. Para pegawai tersebut bisa menunda kepuasaan dirinya dan mengatur perilakunya untuk menyelesaikan pekerjaan yang sedang di tunggu oleh pimpinan mereka. Oleh karena itu kontrol diri berhubungan dalam menentukan perilaku yang dilakukan individu saat bekerja, apakah perilaku yang bersifat produktif atau sebaliknya. Individu bisa dikatakan produktif apabila ia menggunakan fasilitas internet sesuai dengan kebutuhan. Hal ini akan terhindar dari perilaku cyberloafing buruk. Tingkat kontrol 
diri pada individu juga menunjukkan kemampuannya dalam mengatur dan mengarahkan perilakunya kearah konsekuensi yang baik. Sedangkan individu yang mempunyai tingkat kontrol yang rendah cenderung lebih besar untuk melakukan perilaku cyberloafing yang buruk

Temuan ini juga mendukung pernyataan dari Robinson (2008) yang menyatakan bahwa individu yang memiliki kontrol diri tinggi dapat lebih mampu untuk meninjau situasi, menahan godaan dan mengalihkan perhatian mereka dari perilaku merugikan seperti cyberloafing. Sebaliknya apabila individu memiliki kontrol diri rendah, mereka memiliki keperluan yang kuat terhadap perilaku terlarang saat bekerja, seperti perilaku cyberloafing.

\section{SIMPULAN}

Berdasarkan hasil yang diperoleh dari analisis data dan pembahasan, maka peneliti menarik kesimpulan bahwa ada hubungan sangat signifikan antara perilaku cyberloafing dengan kontrol diri pada pegawai administrasi rumah sakit di Palembang.

\section{DAFTAR RUJUKAN}

Ardilasari, N. (2016). Hubungan Self Control dan Perilaku Cyberloafing Pada Pegawai Negeri Sipil. Jurnal Ilmiah Psikologi Terapan, 1, 19-39.

Arikunto, S. (2013). Prosedur Penelitian Suatu Pendekatan Praktik. Jakarta : Rineka Cipta.

Astri, Y. (2014). Pengaruh iklim organisasi terhadap perilaku cyberloafing pada karyawan PT Telekomunikasi Indonesia TKB Medan. USU library: Universitas Sumatra Utara.

Azrul, A. 2010. Pengantar Administrasi Kesehatan. Jakarta : PT Bina Rupa Aksara

Azwar, S. 2012. Penyusunan Skala Psikologi. Yogyakarta: Pustaka Pelajar

Ghufron, M. Nur dan Rini Risnawita S. (2014). Teori-Teori Psikologi. Yogyakarta: Ar-Ruzz Media

Hurriyati, D. (2017). Analisis Faktor-faktor yang Mempengaruhi Perilaku Cyberloafing pada Pegawai Negeri Dinas Pekerjaan Umum Kota Palembang. Jurnal Ilmiah Psyche, 2, 75-86.

Indonesian Consumer Profile. (2009). Industrial Product Reports Analyses. Diakses dari http://databisnis.net/en/industrialproduct-reportsanalyses/1410indonesian-consumer-profile2009.html.

International Telecommunications Union. (2012). Internet Usage in Asia. Diakses dari http://www.internetworldstats.com/st

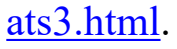


International Telecommunications Union. (2012). Internet Usage Statistics The Internet Big Picture. Tersedia

http://www.internetworldstats.com/st ats.html.

Paramitha, W.N (2016). Hubungan Kontrol Diri Dengan Kecurangan Akademik Pada Mahasiswa Fakultas Teknologi Informasi Universitas Kristen Satya Wacana. (Skripsi, Tidak Diterbitkan). Fakultas Psikologi Universitas Satya Wacana, Salatiga

Robinso, S. L., Bennett, R. J. (2008). A typology of deviant workplace behavior:

A multidimensional scaling study. Academy of Management Journal, $38(2), 555-572$.

Sari, L. (2014). Pengaruh Kontrol Diri Terhadap Perilaku Cyberloafing Pada Pegawai Perpustakaan. (Skripsi, tidak diterbitkan). Fakultas Psikologi Universitas Sumatera Utara, Medan.

Sugiyono. (2013). Statistik Untuk Penelitian. Bandung : Alfabeta.

Utama, J. S. A., Abraham, J., Susana, T., Alfian, I. N., Supratiknya, A. (2016). Psikologi dan Teknologi Informasi. Jakarta : Himpunan Psikologi Indonesia.

Zhang H., Zhao H., Liu J., Xи Y., Lu H (2015). The dampening effect of employees' future orientation on cyberloafing behaviors: the mediating role of self-control. Frontiers in Psychology, 6, 1482.Walgito, B. (2002). Psikologi Sosial (suatu pengantar). Edisi Revisi. Yogyakarta : Andi Offset. 